\title{
Osteochondrosis (OCD) in the tarsocrural joint of Standardbred trotters - Correlation between radio- graphic findings and racing performance
}

\author{
W. Brehm und W. Staecker²
}

Klinik für Nutztiere und Pferde, Fakultät für Veterinärmedizin der Universität Bern, Bern

${ }^{2}$ Klinik für Pferde, Allg. Chirurgie und Radiologie, Fachbereich Veterinärmedizin der Freien Universität Berlin, Berlin

\begin{abstract}
Summary
The tarsocrural joints of 1190 Standardbred trotters were examind radiographically between 1969 and 1986 in the Clinic for Horses, General Surgery and Radiology of the Free University of Berlin as part of a prospective radiological study of the tarsus. Of these, 147 (12.4\%) showed signs of osteochondrosis dissecans (OCD).

The horses did not have surgery for OCD by arthrotomy or arthroscopy.

The racing performance of the horses positiv for $O C D$ and negativ for OCD was compared. Parameters compared were the number of starts, the number of wins, the number of places, the earnings and the maximum speed ever reached. These parameters were compared in the twoyear-olds, the three-year-olds, the four-year-olds and lifetime performance.

No significant differences in racing performance parameters were found between horses with and without radiographic findings of $O C D$.
\end{abstract}

Keywords: $\mathrm{OCD}$, tarsocrural joint, racing performance, longevity, joint, Standardbred trotter

\section{OCD im Tarsokruralgelenk von Trabern Vergleich röntgenologischer Befunde mit der Rennleistung}

Von 1190 während der Jahre 1969 bis 1986 in der Klinik für Pferde, Allgemeine Chirurgie und Radiologie der Freien Universität Berlin im Rahmen einer prospektiven Studie röntgenologisch an den Sprunggelenken untersuchten Trabern wiesen 147, d.h. 12,4\%, Röntgenbefunde im Sinne einer Osteochondrosis dissecans (OCD) auf.

Die Pferde wurden trotz des Befundes im Untersuchungszeitraum nicht arthrotomisch oder arthroskopisch versorgt.

Die Rennlaufbahn der OCD-positiven Traber und der OCD-negativen Traber wurden miteinander verglichen. Als Parameter dienten die Anzahl der Starts, die Anzahl der Siege, die Anzahl der Plätze, die Gewinnsumme und der Kilometerrekord. Die entsprechenden Daten der Pferde als Zweijährige, Dreijährige, Vieriährige und die Lebensrennleistung wurden als Vergleichsklassen berechnet.

Die Rennleistungsdaten der OCD-positiven und der OCD-negativen Traber unterscheiden sich in keiner der Altersklassen und in keinem der Parameter signifikant.

Schlüsselwörter: OCD, Tarsokruralgelenk, Rennleistung, Lebensleistung, Gelenk, Trabrennpferd

\section{Introduction}

Although profound knowledge has been worked out about diagnosis of osteochondrosis of the tarsocrural joint, epidemiology, pathogenesis, therapy and hereditary factors, very few details exist about the relation of the findings and racing performance. The interpretation of the radiological signs of osteochondrosis in the tarsocrural joint remains an important factor in purchase examinations of young horses without clinical symptoms.

Zeller et al. (1978) showed in a retrospective study that $30 \%$ of the horses were positive for OCD of the tarsocrural joints without showing clinical symptoms. Sandgren et al. (1993) pointed out that in contrast with OCD of the fetlock joint, OCD of the tarsocrural joint can lead to clinical signs and may have an impact on the future racing career of these horses. According to Grondahl et al. (1995) OCD in the tarsocrural joint leads to significantly lower number of starts and insignificantly lower earnings in three-year- and four-year-old Standardbreds. On the other hand, Storgard Jorgensen et al. (1997) did not find any significant association between the presence or type of ra- diological abnormalities and performance during two to four racing seasons.

The aim of this study was to show whether the presence of OCDlesions in the tarsocrural joint can alter lifetime racing performance in a group of Standardbreds with OCD of the tarsocrural joint not having surgery for this condition.

\section{Materials and methods}

1190 Standardbred trotters were examined radiographically for alterations of the tarsus. Both tarsi were radiographed in lateral, dorsolateral-plantaromedial and plantarolateral-dorsomedial views. OCD alterations of the sagittal ridge of the tibia and of the lateral trochlear ridge of the talus were found, while there were no lesions of the medial maleolus mentioned in the clinical files. Horses showing these alterations were included in the OCD-positive group. The radiographs were taken for a prospective study conducted to evaluate the development of 
bone spavin in racing Standardbreds. OCD lesions were not the focus of the study, and OCD of the tarsocrural joint was not treated surgically at this time.

The study included any racing Standardbred which was presented at the clinic regardless the reason of its referral. The clinical signs were documented at the time of the radiological examination and, for this study, taken from the clinical documents.

The age of the first radiological examination of the horses varied between 1,5 and 12 years.

Data about racing performance were taken from the statistical publications of the German Standardbred Association. The following parameters were correlated during the racing carreer as two-, three- and four-year-olds:

$<$ number of starts

$<$ number of wins

$<$ earnings

Lifetime performance is defined as the summation of each above mentioned parameter: Sum of starts, sum of wins, sum of places and sum of earnings of each individual horse during his racing career, and its maximum speed ever reached.

Statistical analysis was provided by the Institute of Biometrical Studies of the Faculty of Veterinary Medicine of the Free University of Berlin. Nonparametrical testing (Mann-Whitnes $U$ and Wicoxon W) using the $S A S^{\circledR}$ statistical package. All horses positive for OCD in the tarsocrural joint except for three horses that could not be identified $(n=144)$ were compared with a group of horses $(n=118)$ randomly selected from the 1043 horses negative for OCD.

\section{Results}

OCD in the tarsocrural joint was observed in 147 (12.4\%) of 1190 Standardbred trotters. Of the 147 affected horses, 75 (50.8\%) had a unilateral OCD of the sagittal ridge of the tibia. Fifty-eight of the affected horses (39.5\%) showed bilateral OCD of the sagittal ridge. Fourteen of the horses (9.7\%) had a diagnosis of unilateral OCD of the lateral trochlea of the talus (table 1).

Tab. 1: Distribution of radiological findings of $O C D$ of the tarsocrural joint (TCJ).

Verteilung der radiologischen Befunde von OCD des Tarsokruralgenkes

\begin{tabular}{|l|c|c|c|}
\hline Location of OCD & $\begin{array}{c}\text { Number of } \\
\text { horses }\end{array}$ & $\begin{array}{c}\% \text { of } \\
\text { horses }\end{array}$ & $\begin{array}{c}\% \text { of } \\
\text { OCD }\end{array}$ \\
\hline No OCD & 1043 & 87,6 & 0,0 \\
\hline Sagittal ridge left TCJ & 47 & 3,9 & 31,4 \\
\hline Sagittal ridge right TCJ & 28 & 2,4 & 19,4 \\
\hline Sagittal ridge bilaterally & 58 & 4,9 & 39,5 \\
\hline $\begin{array}{l}\text { Lateral trochlea tali left } \\
\text { TCJ }\end{array}$ & 9 & 0,8 & 6,5 \\
\hline $\begin{array}{l}\text { Lateral trochlea tali } \\
\text { rightTCJ }\end{array}$ & 5 & 0,4 & 3,2 \\
\hline & 1190 & 100 & 100 \\
\hline
\end{tabular}

Clinical signs reported were lameness, effusion of the tarsocrural joint and positive flexion tests of the proximal joints of the hindlimb. As the horses examined for this investigation were sent to the equine hospital for various reasons, correlations between the clinical signs and OCD could not be demonstrated. Problems leading to the respective signs also were deriving from structures not related to the tarsocrural joint. As examples, wounds, bursitis, tendonitis and splint bone fracture were among the diagnoses. Interestingly, unilateral $\mathrm{OCD}$ of the tarsocrural joint was associated with contralateral affection of the $\mathrm{m}$. interosseus medius in some of the cases.

In tables 2, 3, 4, 5 and 6 the number of starts, wins, places, earnings and maximum speed of horses with and without OCD

Tab. 2: Number of starts of horses with and without radiological findings of $O C D$

Anzahl Starts der Pferde mit und ohne radiologische Anzeichen für OCD

\begin{tabular}{|l|l|c|c|c|c|c|}
\hline Age & OCD & $\begin{array}{r}\text { Num- } \\
\text { ber of } \\
\text { horses }\end{array}$ & Mean & STD & Min & Max \\
\hline Two-year & $\begin{array}{l}\text { Control } \\
\text { OCD }\end{array}$ & $\begin{array}{l}118 \\
144\end{array}$ & $\begin{array}{l}1 \\
1\end{array}$ & 2 & 0 & 7 \\
& OCD & 9 \\
\hline & Control & 118 & 5 & 6 & 0 & 25 \\
& OCD & 144 & 5 & 6 & 0 & 25 \\
\hline & Control & 118 & 9 & 9 & 0 & 36 \\
Four-year & OCD & 144 & 9 & 9 & 0 & 37 \\
\hline Lifetime & Control & 118 & 51 & 50 & 0 & 239 \\
performance & OCD & 144 & 55 & 50 & 0 & 273 \\
\hline
\end{tabular}

Tab. 3: Number of wins of horses with and without radiological findings of OCD.

Anzahl Siege der Pferde mit und ohne radiologische Anzeichen für OCD

\begin{tabular}{|l|l|c|c|c|c|c|}
\hline Age & OCD & $\begin{array}{l}\text { Num- } \\
\text { ber of } \\
\text { horses }\end{array}$ & Mean & STD & Min & Max \\
\hline Two-year & Control & 118 & 0 & 0 & 0 & 2 \\
144 & 0 & 0 & 0 & 2 \\
\hline Three-year & Control & 118 & 1 & 1 & 0 & 7 \\
144 & 1 & 2 & 0 & 12 \\
\hline Four-year & Control & 118 & 2 & 2 & 0 & 9 \\
& OCD & 144 & 2 & 3 & 0 & 17 \\
\hline Lifetime & Control & 118 & 6 & 8 & 0 & 35 \\
performance & OCD & 144 & 8 & 11 & 0 & 60 \\
\hline
\end{tabular}


during their racing career are listed. No statistically significant difference between horses with and without OCD of the tarsocrural joint in any of the parameters was found. Mean values were close together and standard-deviations partially exceeded mean values.

Tab. 4: Number of places of horses with and without radiological findings of $\mathrm{OCD}$

Anzahl Platzierungen von Pferden mit und ohne radiologische Anzeichen für OCD

\begin{tabular}{|c|c|c|c|c|c|c|}
\hline Age & $O C D$ & $\begin{array}{l}\text { Num- } \\
\text { ber of } \\
\text { horses }\end{array}$ & Mean & STD & Min & Max \\
\hline Two-year & $\begin{array}{l}\text { Control } \\
\text { OCD }\end{array}$ & $\begin{array}{l}118 \\
144\end{array}$ & $\begin{array}{l}0 \\
1\end{array}$ & $\begin{array}{l}1 \\
1\end{array}$ & $\begin{array}{l}0 \\
0\end{array}$ & $\begin{array}{l}5 \\
6\end{array}$ \\
\hline Three-year & $\begin{array}{l}\text { Control } \\
\text { OCD }\end{array}$ & $\begin{array}{l}118 \\
144\end{array}$ & $\begin{array}{l}2 \\
2\end{array}$ & $\begin{array}{l}3 \\
3\end{array}$ & $\begin{array}{l}0 \\
0\end{array}$ & $\begin{array}{l}15 \\
12\end{array}$ \\
\hline Four-year & $\begin{array}{l}\text { Control } \\
\text { OCD }\end{array}$ & $\begin{array}{l}118 \\
144\end{array}$ & $\begin{array}{l}4 \\
4\end{array}$ & $\begin{array}{l}4 \\
5\end{array}$ & $\begin{array}{l}0 \\
0\end{array}$ & $\begin{array}{l}16 \\
23\end{array}$ \\
\hline $\begin{array}{l}\text { Lifetime } \\
\text { performance }\end{array}$ & $\begin{array}{l}\text { Control } \\
\text { OCD }\end{array}$ & $\begin{array}{l}118 \\
144\end{array}$ & $\begin{array}{l}20 \\
22\end{array}$ & $\begin{array}{l}22 \\
24\end{array}$ & $\begin{array}{l}0 \\
0\end{array}$ & $\begin{array}{l}133 \\
121\end{array}$ \\
\hline
\end{tabular}

Tab. 5.: Earnings (DM) of horses with and without radiological findings of OCD

Gewinnsumme (DM) von Pferden mit und ohne radiologische Anzeichen für $O C D$

\begin{tabular}{|c|c|c|c|c|c|c|}
\hline Age & OCD & $\begin{array}{l}\text { Num- } \\
\text { ber of } \\
\text { horses }\end{array}$ & Mean & STD & Min & Max \\
\hline Two-year & $\begin{array}{l}\text { Control } \\
O C D\end{array}$ & $\begin{array}{l}118 \\
144\end{array}$ & $\begin{array}{l}1634 \\
1840\end{array}$ & $\begin{array}{l}5588 \\
7059\end{array}$ & $\begin{array}{l}0 \\
0\end{array}$ & $\begin{array}{l}40680 \\
67069\end{array}$ \\
\hline Three-year & $\begin{array}{l}\text { Control } \\
\text { OCD }\end{array}$ & $\begin{array}{l}118 \\
144\end{array}$ & $\begin{array}{l}3204 \\
5065\end{array}$ & $\begin{array}{l}11634 \\
11899\end{array}$ & $\begin{array}{l}0 \\
0\end{array}$ & $\begin{array}{l}121910 \\
104123\end{array}$ \\
\hline Four-year & $\begin{array}{l}\text { Control } \\
\text { OCD }\end{array}$ & $\begin{array}{l}118 \\
144\end{array}$ & $\begin{array}{l}6288 \\
7599\end{array}$ & $\begin{array}{c}8117 \\
13179\end{array}$ & $\begin{array}{l}0 \\
0\end{array}$ & $\begin{array}{l}32100 \\
92500\end{array}$ \\
\hline $\begin{array}{l}\text { Lifetime } \\
\text { performance }\end{array}$ & $\begin{array}{l}\text { Control } \\
\text { OCD }\end{array}$ & $\begin{array}{l}118 \\
144\end{array}$ & $\begin{array}{l}30304 \\
40504\end{array}$ & $\begin{array}{l}42474 \\
64221\end{array}$ & $\begin{array}{l}0 \\
0\end{array}$ & $\begin{array}{l}215300 \\
428500\end{array}$ \\
\hline
\end{tabular}

\section{Discussion}

The percentage of OCD in the tarsocrural joints of Standardbred trotters is comparable to percentages found by other investigators looking at a similarly high number of horses. Grondahl (1991) found 14,3\% of OCD in a group of 753 Standardbreds, $45,4 \%$ of those showing bilateral problems. Sandgren et al. (1993) reported $11,5 \%$ of OCD in the tarsocrural joint in 793 standardbreds with $45 \%$ bilateral signs, $5 \%$ at the lateral trochlea tali. The distribution among the limbs in our study also reflects the situation described in the literature.

Tab. 6: Lifetime maximum speed (seconds over one minute per kilometer) achieved of horses with and without radiological findings of OCD

Maximal erzielte Geschwindigkeit (beste, je gelaufene Zeit des einzelnen Pferdes) in Sekunden über 1 Minute bei Pferden mit und ohne radiologische Anzeichen für $\mathrm{OCD}$

\begin{tabular}{|c|c|c|c|c|c|c|}
\hline Age & OCD & $\begin{array}{l}\text { Num- } \\
\text { ber of } \\
\text { horses }\end{array}$ & Mean & STD & Min & Max \\
\hline $\begin{array}{l}\text { Lifetime } \\
\text { performance }\end{array}$ & $\begin{array}{c}\text { Control } \\
\text { OCD }\end{array}$ & $\begin{array}{l}106 \\
144\end{array}$ & $\begin{array}{l}22,38 \\
22,46\end{array}$ & $\begin{array}{l}3,87 \\
4,43\end{array}$ & $\begin{array}{l}14,6 \\
14,4\end{array}$ & $\begin{array}{l}34,9 \\
43,2\end{array}$ \\
\hline
\end{tabular}

The clinical evaluation shows that $O C D$ in the tarsocrural joint is not necessarily causing clinical signs. This also is in agreement with other authors (Zeller et al., 1978; Peremans and Verschooten, 1997).

The comparison of the racing performance of horses affected with OCD of the tarsocrural joint but not treated surgically with horses not affected with this condition showed no significant differences in the parameters "number of starts", "number of wins", "number of places", "earnings" or "maximum speed". This is in accordance with the results of Alvarado et al. (1990) and Storgard-Jorgensen et al. (1997) for the two-year-olds, the three-year-olds and the four-year-olds, but in contradiction to Grondahl and Engeland (1995), where a negative effect of OCD in the tarsocrural joint on the racing performance was postulated. This negative effect, however, was significant only for the number of starts, while the tendency to lower earnings was not significant. As these horses were examined as yearlings alrea$d y$, the awareness of the trainers may have led to fewer starts and earnings. The material of our originally prospective, study, however, was only evaluated retrospectively, and the radiological signs of $O C D$ in the tarsocrural joint were not judged to be of high clinical importance at the time of the examination.

For the first time results of lifetime racing performance data are here reported. According to our results for the young horses, no significant differences in the lifetime racing performance were observed when comparing the above mentioned parameters. In the clinical situation, joung standardbreds are radiographed for purchase examination, and the presence of OCD signs in the tarsocrural joints will always raise the question for the significance for the future of the individual. Our data support the finding that there is no general indication for preventative surgery when we look at the overall population. Most of the horses showing signs of OCD in the tarsocrural joint would race without developing clinical problems at this site.

Therefore, we deal with the problem according to the proposal of Zeller et al. (1978). Horses with joint effusion and/or lameness from the tarsocrural joint and/or postive flexion tests of the respective joint are candidates for arthroscopic surgery. This is supported by Peremans and Verschooten (1997) who recommend surgery for Standardbreds when presented with clinical 
symptoms associated with radiologic signs of hock OCD. The surgical procedure is safe (Laws et al., 1993; Bramlage et al., 1994), and not performing surgery could result in greater expense (spent training fees etc.) than early surgery. Horses without one of the clinical signs, however, can be trained without preventative surgery and the risk of problems in the OCD-affected joint is low.

\section{References}

Alvarado A.F., M. Marcoux and L. Breton (1990): The incidence of osteochondrosis in a Standardbred breeding farm in Quebec. Am. Ass. Equine Pract. Proceedings of the $35^{\text {th }}$ Ann. Conv. Boston, 1990, 293-307

Beard W.L., L.R. Bramlage, R.K. Schneider and R.M. Emertson (1994): Postoperative racing performance in Standardbreds and Thoroughbreds with osteochondrosis of the tarsocrural joint: 109 cases (19841990). JAVMA, 1994; 204, 1655-1659

Grondahl A.M. (1991): The incidence of osteochondrosis in the tibiotarsal joint of Norvegian Standardbred Trotters. Equine vet sci, 1991 ; $11,272-274$

Grondahl A.M. and A. Engeland (1995): Influence of radiographically detectable orthopedic changes on racing performance in Standardbred trotters. JAVMA, 1995; 206, 1013-1017

Laws E.G., D.W. Richardson, M.W. Ross and W. Moyer (1993): Racing performance of Standardbreds after conservative and surgical treatment for tarsocrural osteochondrosis. Equine vet. J., 1993; 25, $199-$ 202
Peremans K. and F. Verschooten (1997): Results of conservative treatment of osteochondrosis of the tibiotarsal joint in the horse. J. equine vet. sci., 1997; 17, 322-326

Sandgren B., G. Dalin and J. Carlsten (1993): Osteochondrosis in the tarsocrural joint and osteochondral fragments in the fetlock joints in Standardbred trotters. I. Epidemiology. Equine vet J Suppl, 1993; $16,31-37$

Storgard-Jorgensen H, H. Proschowsky, J. Falk-Ronne, et al. (1997): The significance of routine radiographic findings with respect to subsequent racing performance and longevity in Standardbred trotters. Equine vet J, 1997; 29, 55-59

Zeller R., B.Hertsch und M.T. Samy (1978): Vorkommen und klinische Bedeutung der Osteochondrosis dissecans (O.d.) im Talokruralgelenk beim Pferd. Dtsch Tierärzłl Wschr, 1978; 85, 223-226

Dr. med. vet. Walter Brehm

Klinik für Nutztiere und Pferde Universität Bern

Laenggass-Strasse 124

$\mathrm{CH} 3012$ Bern

Dr. med. vet Wolfgang Staecker

Klinik für Pferde

Allg. Chirurgie und Radiologie

Freie Universität Berlin

Oertzenweg 19 b

D 14163 Berlin 